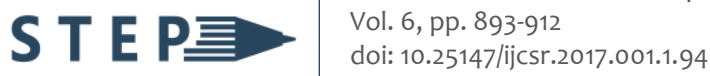 \\ https://stepacademic.net
}

\section{Long Paper \\ Uses of Telehealth in Elderly Patients during COVID-19 \\ Pandemic: An Integrative Review}

Roison Andro Narvaez

St. Paul University Philippines; St. Paul University Manila, Philippines; University of Makati, Philippines

rnarvaez@spup.edu.ph

(corresponding author)

Marilane Ferrer

University of Makati, Philippines

Ralph Antonio Peco

University of Makati, Philippines

Neil Bryant Sangilan

University of Makati, Philippines

Ronalyn Topacio

University of Makati, Philippines; Centro Escolar University, Philippines

Date received: January 10, 2022

Date received in revised form: January 23, 2022

Date accepted: January 26, 2022

Recommended citation:

Narvaez, R.A., Ferrer, M., Peco, R.A., Sangilan, N.B., \& Topacio, R. (2022). Uses of telehealth in elderly patients during COVID-19 pandemic: An integrative review. International Journal of Computing Sciences Research, 6, 893-912. doi: 10.25147/ijcsr.2017.001.1.94

\section{Abstract}

Purpose - The coronavirus disease-19 (COVID-19) epidemic is a significant public health concern on a global scale. Telehealth could be used to combat the COVID-19 outbreak. During the COVID19 epidemic, the goal of this integrative review was to examine the applications, functions, and consequences of telehealth services in preventing disease, 
diagnosis, medication, and mitigation, especially in long-term care settings or in elderly patients.

Method - The five web databases searched were PubMed, ResearchGate, Google Scholar, Web of Science, and Science Direct. The inclusion criteria were studies that documented the explicit use of telehealth services in all elements of health care for older adults during the COVID-19 outbreak, were written in English, and were published in e-journals. The Critical Appraisal Skills Program (CASP) checklist was used to determine the quality (McMaster University Hamilton, 2011). The findings were tabularized.

Results - Out of 69 search results, eight studies met the criteria for inclusion. Telehealth is currently an effective method for healthcare practitioners, front liners, COVID19 patients, especially the elderly, who are self-isolating to reduce the risk of COVID-19 transmission. This technique can significantly eliminate direct physical contact, maintain community care, and eventually minimize COVID-19 outbreak morbidity and mortality.

Conclusion - Telehealth simplifies the process of providing health care to the elderly. As a result, telehealth should be a vital component of providing care while also safeguarding older patients and health care providers throughout the COVID-19 outbreak.

Implications - Telehealth was highly used in the COVID19 pandemic era. The specific uses and functions of telehealth during the pandemic, specifically to the elderly, is significant in the aspect of patient care.

Keywords - COVID-19, telehealth, elderly patients, healthcare, integrative review

\section{INTRODUCTION}

Coronaviruses are a subfamily of coronaviridae viruses capable of infecting both animals and humans (WHO, 2020; van der Hoek et al., 2004). Numerous coronaviruses have been linked to human respiratory diseases ranging from the common cold to severe conditions. Coronavirus disease-19 (COVID-19) is caused by a newly discovered coronavirus (WHO, 2020). The disease began in Wuhan, China, and has since spread worldwide (Lipsitch et al., 2020). The initial signs of COVID-19 include fever, a dry cough, trouble breathing, and dullness (Huang et al., 2020; F. Jiang, et al., 2020; X. Jiang et al., 2020). Seniors and individuals with pre-existing medical conditions such as hypertension, heart disease, or diabetes are more likely to develop the disease in its most severe form (WHO, 2020). According to the World Health Organization (2020), this pandemic is global. Restricting person-to-person contact is crucial for limiting the further spread of the virus (Smith et al., 2020; Hollander et al., 2020) 
Natural catastrophes and epidemics impose a range of constraints on the provision of health care (Chauhan et al., 2020). Globally, travel restrictions have been created and enforced, and most cities have been quarantined to contain the virus's spread (Papadimos et al., 2018). Individuals who are not infected with COVID-19, particularly those at a higher risk of infection (e.g., the elderly and those with underlying illnesses), should continue getting daily treatment without fear of contracting the disease from other hospital patients (Smith et al., 2020). Additionally, non-essential workers, such as clinical psychiatrists, are strictly prohibited from entering the COVID-19 patient unit due to tight infection control procedures (W. Li et al., 2020; Kang et al., 2020). As a result, creative and unique solutions are necessary to meet the critical healthcare needs of COVID-19 patients and other individuals in need of care. Technological improvements have facilitated new opportunities in this industry (Wax \& Christian, 2020). While the ultimate COVID-19 solution will be sophisticated, it is one of the most effective ways to leverage existing technology to deliver efficient services while eliminating the risk of direct individual transference (Smith et al., 2019; T. Zhou et al., 2020). Telemedicine adoption during epidemics (such as the COVID-19 pandemic) can substantially increase epidemiology study, disease prevention, and case reports management (Ohannessian, 2015; Smith et al., 2020; T. Zhou et al., 2020; Adhikari et al.,2020).

Telehealth is a twenty-first-century patient-centered strategy that protects patients, physicians, and others (Kruse et al., 2017; Campion et al., 2016). Telehealth is the delivery of health care services over significant distances by providers that rely on information and communication technologies to transmit correct and reliable data (WHO, 2010). Telehealth services can be delivered in real-time or in batches (Bradford et al., 2015). Due to the rapid development and downsizing of portable electronics, most families now own at least one digital device, such as cellphones (Valle et al., 2017) or webcams that enable patients and healthcare providers to communicate (Jahanshir et al., 2017). Video conferencing and similar media technologies are also used to provide health care to unwell or isolated individuals to reduce the danger of infection to others and employees (Smith et al., 2020). These services are accessible to confined physicians caring for foreign-national patients (Canady, 2020; Hollander et al., 2020). Having a tele-physician cover, many sites can also help with workforce concerns (Hollander et al., 2020; Fortney et al., 2007).

Telehealth technology offers substantial benefits, particularly for regular nonemergency treatment services that do not allow physical patient-provider interaction, such as psychiatric therapies (Fortney et al., 2007). Remote care minimizes healthcare resource consumption, increases access to care, and decreases the risk of infectious disease transmission from person to person (Charles, 2000). Apart from ensuring the general public's safety, patients, and health professionals, another significant benefit is expanding access to care providers (Chauhan et al., 2020). As a result, this strategy is appealing, practical, and cost-effective (T. Zhou et al., 2020; Mehrotra et al., 2016; SauersFord et al., 2019). Although patients desire to use Telemedicine, various barriers exist (Portnoy et al., 2020; Morenz et al., 2019). Accreditation, payment mechanisms, and 
insurance are all significant impediments to the adoption of these programs (Hollander et al., 2020). Additionally, some doctors are concerned with technical and clinical quality and safety, privacy, and accountability (Greenhalgh et al., 2020b).

Telehealth may become a necessity for ordinary people, health care providers, and COVID-19 patients, particularly during isolation times, allowing patients to seek actual counseling on their health problems via discussion with a health care provider, most specifically for the elderly.

In many regions of the world, the COVID-19 outbreak has disproportionately afflicted the elderly. According to one study, persons over 65 face a 100-fold increase in mortality risk compared to those in lower age categories (Ioannidis et al., 2020). Numerous factors, including biological, behavioral, demographic, healthcare access, and social determinants, contribute to older adults' heightened vulnerability to respiratory epidemics such as COVID-19 (Doraiswamy et al., 2020). Among these concerns is the rising lack of affordable healthcare options for the senior population. Numerous factors contributed to the current pandemic, including (a) an overburdened healthcare system that was unable to prioritize the needs of older people, (b) movement restrictions and lockdowns imposed to prevent disease transmission, as well as the difficulties older people face when attempting to access medical clinics, and (c) widespread fear and concern among older people and their caregivers about contracting COVID-19 while receiving treatment in physical clinics (Sathyanarayanan et al., 2021).

Global excitement towards telehealth services in various sectors, including older adults, is growing. Following the outbreak of the COVID-19 pandemic, nations began to ease legislative prohibitions on the use of telehealth in patient care, resulting in a rapid increase of telehealth services globally. Before COVID-19, few insurance companies covered some telehealth services; nevertheless, the scope and extent of telehealth coverage have increased significantly throughout the epidemic (Foster \& Sethares, 2014; Wosik et al., 2020). Different methods for telehealth services to older adults arose during the epidemic (Tan et al., 2020).

The purpose of this research was to determine and describe the roles and uses of telehealth services in preventing disease, developing treatment plans, administering therapies, and regulating the illness during the COVID-19 outbreak, specifically to older patients.

\section{PICOT QUESTION}

The question of this review was: With the experiences of elderly patients $(P)$ of using telehealth (I), what are its uses and effects (O) as they were used in the COVID 19 pandemic $(T)$ ? 


\section{METHODS}

\section{Research Design}

This paper is designed as an integrative review of the literature. Southern Connecticut University (2021) states that integrative reviews incorporate nonexperimental research, like case studies, naturalistic studies, and meta-analyses, but may also include practical applications, theory, and guidelines. Search, scanning then selection criteria should be well-detailed and accurate.

\section{Quality Assessment}

The quality of the research included was assessed using the Critical Appraisal Skills Program (CASP) criteria (McMaster University Hamilton, 2011).. The CASP tools were aimed at guiding and giving frameworks to researchers to evaluate various types of evidence critically (Popay et al., 2006). The overall quality of the research analyzed was outstanding. Six studies (75\%) were of excellent quality, whereas two $(25 \%)$ were medium quality. Additionally, no study was removed due to quality deficiency. Table 1 Summarizes the quality assessment results of the article selection with level of evidences.

\section{Search Strategy}

PubMed, ResearchGate, Google Scholar, Web of Science, and Science Direct, the five web databases searched due its freely available web search databases indexing full texts and scholarly papers. However, Springerlink, Scopus, Taylor \& Francis, EbscoHost was excluded due to the limitation of researchers' accessibility. The search was conducted using titles and abstracts. The researcher conducted manual web resource searches on Google, Google Scholar, journals that published significant studies due to its array of biomedical and life sciences topics, and specific websites such as the World Health Organization and other reputable government-sponsored public information websites. Additionally, the researcher checked the references sections of the selected publications to determine if any further studies or reports were missed during the initial searches. A direct manual search was encoded with keyword input such as COVID19, old patients, telehealth, telecommunication for medical care, aged patients, and telehealth services for the elderly.

\section{Criteria of Eligibility}

In this research, the researcher analyzed all studies that presented evidence for the role of telehealth services in COVID-19 and the elderly. Indeed, studies were evaluated if they explicitly discussed the role of telehealth in preventing, diagnosing, managing, and treating COVID-19, were peer-reviewed, and then were published in English. December 31, 2021 was chosen as the marking date because it corresponds to the launch of COVID-19 in 
Wuhan, Hubei Province, China until May 31, 2020. Indeed, any study that employed telehealth tools to deliver clinical services, diagnosis, symptom assessment, patient screening, consultation, or practitioner training or monitoring in any health care sector was included. Additionally, alternative technical research, duplicate publications, review articles, opinion articles, and letters that omitted primary data, as well as studies with insufficient data, were rejected.

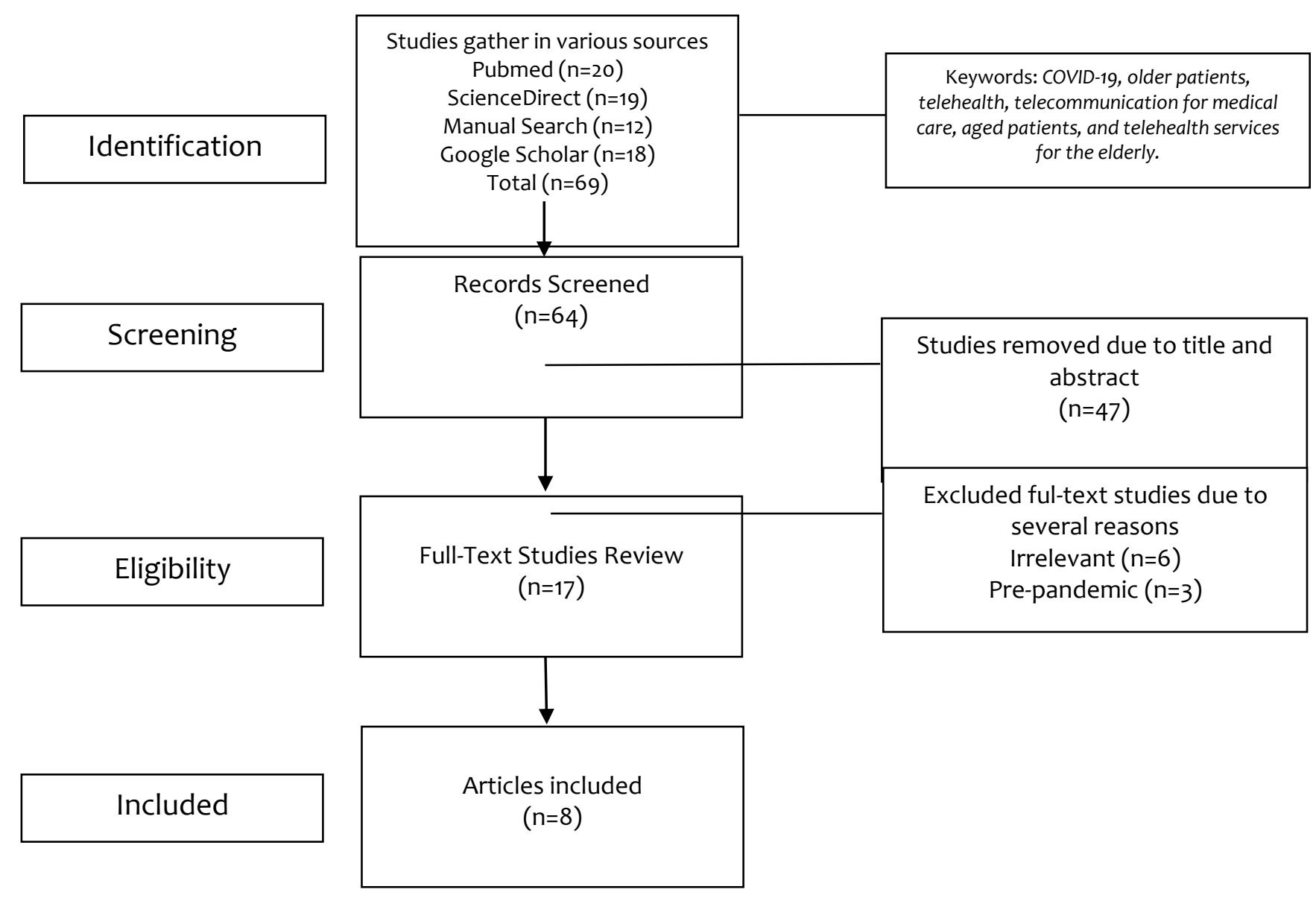

Figure 1. Search Strategy and Data Selection of Studies Related to Uses of Telehealth on Elderly Patients During the COVID-19 Pandemic

\section{RESULTS}

Table 1 (See Appendix) summarizes the significant parts of the research that were considered. The plurality of the investigations included in this study was executed in the United States, and they were published in a variety of international publications within that period. Eight studies were conducted in six countries: United States, Canada, China, the United Kingdom, and Hongkong. The United States ranked first in terms of number. This review comprised cross-sectional studies, case studies, descriptive -retrospective, 
descriptive pilot, raw descriptive, and one case-control research. The majority of health department which serve as the research setting is under COVID19 health care.

\section{DISCUSSION}

\section{Telehealth for the Elderly in the COVID-19 Pandemic}

On the basis of the researcher's findings, the researcher identified ten studies that provided valuable telehealth information on elderly during the pandemic. Telehealth is a method of integrating many businesses and healthcare scenarios into a centralized virtualized network environment. In addition to physical facilities throughout the country, such as central and distant clinics, preventative centers, private clinics, private healthcare centers, and rehabilitation centers, this network may include any and all of the patients who have been listed in those locations. By leveraging virtual care for very routine, critical medical care and deferring elective treatments like yearly exams, we may be able to free up medical staff and equipment to deal for patients who get critically ill as a result of COVID-19, which is currently being investigation. In addition, by avoiding packed areas such as waiting rooms, the coronavirus's ability to spread was decreased, which was beneficial.

The concept of "social distancing" refers to the process through which people maintain a sense of separation from one another in social situations. When it comes to patients and other service providers, it is typical for medical workers to keep a certain amount of distance. Telehealth is one example of a technology that, at the moment, may be able to assist us in this attempt.

Healthcare has the potential to be mobilized in all aspects, including disease transmission reduction, directing people to the appropriate level of care, ensuring the security of online health services, protecting patients and clinicians from infection, and reducing the burden on healthcare providers the health system. Telehealth should play a vital part in the fight against the COVID-19 pandemic, ensuring that people continue to have access to life-saving medical treatments in the event of an outbreak. A few examples of patient-centered telehealth applications include COVID-19 epidemic control and triage, self- and remote monitoring, treatment, patients discharged from healthcare facilities (follow-ups), and adoption of online health services. In the case of a pandemic, these strategies have the potential to reduce morbidity and mortality drastically. Despite minor symptoms, all health care workers and healthcare professionals can continue to work in remote locations with patients, enabling rapid access to appropriate decisionmaking, obtaining expert advice for individuals with symptomatic cases, exchanging cross-border perspectives, and providing health workers with teleradiology and online training. 
A significant study conducted during the COVID-19 pandemic aimed to determine the effectiveness of telehealth services in the areas of disease mitigation, diagnosis, treatment, and prevention. Table 2 summarizes the specific telehealth platforms that were being used in the said studies while Table 3 (See Appendix) summarizes Telehealth, its function and its effects on the elderly patients.

Table 2. Specific Telehealth Platforms

\begin{tabular}{|l|l|}
\hline Author/Year/Country & Telehealth Platform \\
\hline Choi et al. (2021) United States of America & $\begin{array}{l}\text { phone calls, emails, texts or social media } \\
\text { messages, and video calls (including Zoom, } \\
\text { FaceTime, and other online } \\
\text { videoconferencing) }\end{array}$ \\
\hline Zhai e.t al. (2020) China, United Kingdom & $\begin{array}{l}\text { Mobile video conferencing and live video } \\
\text { conferencing }\end{array}$ \\
\hline L. Liu et al. (2020) China & $\begin{array}{l}\text { Calls and a computerized health record } \\
\text { (EHR) }\end{array}$ \\
\hline $\begin{array}{l}\text { Nicol et al. (2020) United States of America, } \\
\text { Canada }\end{array}$ & $\begin{array}{l}\text { Telephone, email, and videoconferencing are } \\
\text { examples of digital channels that can be } \\
\text { used in conjunction with social media }\end{array}$ \\
\hline $\begin{array}{l}\text { H. Li. et al. (2020) } \\
\text { Hong Kong }\end{array}$ & $\begin{array}{l}\text { Phones, video cameras, and laptop } \\
\text { computers }\end{array}$ \\
\hline $\begin{array}{l}\text { Tenforde et al. (2020) } \\
\text { United States of America }\end{array}$ & $\begin{array}{l}\text { Phone, electronic medical record, messaging } \\
\text { via patient portal, digital photography, } \\
\text { videography on a HIPAA-compliant platform, } \\
\text { and website }\end{array}$ \\
\hline Pereira et al. (2020) United States of America & Online monitoring gadgets \\
\hline Lam et al. (2020) United States & Video visits/ video conference \\
\hline
\end{tabular}

Healthcare personnel can communicate with patients via telecommunications technology for the purposes of triage, assessment, and care, therefore lowering the number of people who require face-to-face medical attention (National Center for Immunization and Respiratory Diseases (U.S.). Division of Viral Diseases, 2020).). Health care clinicians can ask precise questions and collect crucial information, such as patient triage and supply consultation, using live video conferencing or a simple telephone conversation. They can also determine whether a patient can continue to self-monitor symptoms from home while healing. Additional applications include the ability to perform routine blood pressure, respiration rate, and oxygen saturation level readings in the comfort of your own home (Zhai, et al., 2020).

On Weibo, WeChat, and TikTok, mental health practitioners and government officials were able to provide safe mental health therapies to those affected by the COVID-19 pandemic (Lui et al., 2020). To maintain the continuation of mental health 
services and to reduce the risk of cross infection, Chinese officials established a remote consultation network capable of conducting secure internet or telephone consultations (X. Jiang, et al., 2020). The Chinese National Health Commission has also developed a series of online guidelines and freely available electronic publications on COVID-19 to assist Chinese citizens with emergency response, safety, and increasing the quality and effectiveness of emergency response ( $\mathrm{H}$. Li et al., 2020). Telemedicine can also be used to deliver mental online health therapy to isolated individuals by alleviating COVID-19 mental health challenges and disseminating information on symptoms such as weariness, sadness, anxiety and depression (X. Zhou et al., 2020).

Employees should use mobile health technology to arrange personnel and bill for quality treatment, as well as to ensure the health and safety of patients (Shaker et al., 2020) according to the American Hospital Association. To the contrary, Greenhawt et al. (2020) argued that using Telemedicine for allergy and immunology therapy delivery has a lot of advantages, including reducing health workers' exposure to possibly infected patients and facilitating quick COVID-19 illness evaluation. During Iran's severe COVID-19 pandemic, the researchers identified an unique testing and triage procedure that may be used in conjunction with standard methods for COVID-19 detection. A social media massager was formed by the Iranian Society of Radiology (ISR) during the COVID-19 outbreak to give teleradiology and teleconsultation alternatives for COVID-19 infection evaluation (Davarpanah, et al., 2020).

Using video consultations and telephone follow-up, cancer patients with lung, endometrial, colorectal, and prostate cancer can be helped to contain the COVID-19 epidemic (Simcock, 2020; Soroosh \& Javadinia, 2020). The findings indicate that live video consultation can be used to manage COVID-19 in a variety of fundamental ways, including but not limited to: Using live video conferencing to communicate with physicians and other healthcare professionals reduces the risk of respiratory secretion exposure and infection transmission (Yang, et al., 2020). This is because it eliminates direct physical contact, which reduces the risk of respiratory secretion exposure and infection transmission. Besides that, live video may be beneficial for patients seeking guidance on covid-19, for concerned individuals, for chronic condition reviews (such as diabetes and cancer), for certain prescription checks, and for triage in circumstances where telephone cannot be used (Greenhalgh, et al., 2020a).

An American study by Reeves (2020) found that phone conversations and electronic health records (EHR) can be used to screen and treat patients without the need for in-person visits, as well as to improve decision-making among healthcare teams in ambulatory and urgent care settings, without compromising patient safety. It was critical during the COVID-19 epidemic that Telemedicine was utilized to reduce morbidity while keeping the general population away from high-risk sites such as hospital grounds. Elderly people can also obtain health care through the use of technological equipment (Nicol et al., 2020). Several factors, including financial and service coordination concerns and the inability of local systems to adapt sufficiently, are preventing widespread use of 
Telemedicine to treat COVID-19 infection (Hollander et al., 2020). Finally, we hope to make substantial progress toward diagnosing and controlling the COVID-19 pandemic by providing further training to health care practitioners and patients on the proper use of telehealth tools, reframing clinical practice, and using closed digital sites, among other measures.

As a result of the pandemic, it was proved that telehealth may be used to ensure continuity of geriatric care while also minimizing the need for hospital visits, hence decreasing the risk of infection. According to the findings of this study, the majority of the papers examined were authored in high-income countries, most notably in the United States of America (USA), and were published in geriatric journals in these countries. As previously reported, the vast majority of telehealth studies are carried out in high-income countries, with the United States being the leader in this category. These times, the access to and use of telehealth services for older individuals increased in high-income countries. Governments relaxing restrictions on healthcare delivery, as well as insurance companies adding telehealth as an eligible service in countries such as USA, have all contributed to this development. These aren't true for countries with low and middle incomes, which have a paucity of telehealth literature on their shelves.

Through the entirety of the pandemic, telehealth services for older people were routinely utilized in both the home and long-term care settings. Telehealth has been used as a complement in long-term care settings to permit the collecting of advice from various clinicians at the same time. According to the papers in this investigation, telehealth can be utilized to deliver a wide range of healthcare services, including preventative, curative, and rehabilitative therapies, with a particular emphasis on curative therapy, to patients.

In addition, there is a greater body of literature on the use of Telemedicine for neuropsychiatry services than there is on the use of other specialty therapies in the curative care delivered to older persons during the pandemic, which is encouraging. This discovery is consistent with the reality that the vast majority of telehealth services are used to treat individuals who are frail or suffering from Alzheimer's disease or another dementia. Other medical professionals appear to be using telehealth to provide care to the elderly in a limited number of situations, according to the evidence available thus far. On the other hand, Telemedicine has a long history of use in fields other than geriatric health care, such as dermatology, pathology, and radiology, and is becoming increasingly popular. In the future, there will be several opportunities to provide a variety of telehealth services to the senior population.

Several of the publications in this evaluation were empirical in character, indicating that additional research is required to provide high-quality evidence about senior telehealth utilization. Despite this, the evidence that is now accessible is quite valuable. Prior to the implementation of COVID-19, elderly adults were rarely offered telehealth services due to their incapacity to operate essential equipment. Although older 
individuals' interest in and use of telehealth grew during the COVID-19 outbreak, according to the bulk of the research analyzed, this trend continued after the epidemic ended. In the case of Telemedicine offered in an age-appropriate manner that includes active engagement by older persons and their healthcare professionals, we can predict a higher level of service acceptability.

\section{LIMITATIONS}

This systematic review has three limitations, which are as follows: First, some important study was likely neglected because it was published in a language other than the English language. Second, several databases were inaccessible to us at the time of writing. Third, despite our best attempts to conduct a thorough search and include a diverse variety of data from around the world, further research on this subject may exist in the literature that went unnoticed and unanalyzed during during the search and analysis.

\section{CONCLUSIONS}

This study reviews the potential for telehealth in the case of a COVID-19 pandemic with regards to elderly patients. The purpose of this study was to determine the roles, functions, and effects of telehealth during the COVID-19 pandemic in response to the WHO's call for research on the virus and to provide health care providers with the most up-to-date evidence available at this early stage of the outbreak. As the COVID-19 pandemic spreads exponentially around the globe, recommendations for expanding the use of telehealth as more than just an innovative response show unfulfilled gaps in the worldwide healthcare system. The use of telehealth could overcome numerous significant obstacles related to providing health care even during COVID-19 outbreak. Furthermore, Telemedicine helps us avoid direct physical contact, reduce the risk of COVID transmission, and provide care to the entire community. Clinicians and patients, especially the elder ones, are strongly encouraged to consider telehealth as a viable approach for avoiding and regulating COVID-19 infection, as established by the outcomes of this review study.

\section{RECOMMENDATIONS}

Future research will be the most challenging thing for determining what health professionals and patients think about telehealth and how they are satisfied. The following study should examine how telemedicine solutions improve operational efficiency and hospital performance. In addition, more research around the world is needed to figure out the best way to use telehealth in elderly care. 


\section{REFERENCES}

Adhikari, S. P., Meng, S., Wu, Y. J., Mao, Y. P., Ye, R. X., Wang, Q. Z., Sun, C., Sylvia, S., Rozelle, S., Raat, H., \& Zhou, H. (2020). Epidemiology, causes, clinical manifestation and diagnosis, prevention and control of coronavirus disease (COVID-19) during the early outbreak period: a scoping review. Infectious Diseases of Poverty, 9(1). https://doi.org/10.1186/s40249-020-00646-x

Bradford, N. K., Caffery, L. J., \& Smith, A. C. (2016). Telehealth services in rural and remote Australia: a systematic review of models of care and factors influencing success and sustainability. Rural and remote health, 16(4), https://pubmed.ncbi.nlm.nih.gov/27744708/

Canady, V. A. (2020). COVID-19 outbreak represents a new way of mental health service delivery. Mental Health Weekly, 30(12), 1-4. https://doi.org/10.1002/mhw.32282

Charles, B. L. (2000). Telemedicine can lower costs and improve access. Healthcare financial management : Journal of the Healthcare Financial Management Association, 54(4), 66-69. https://pubmed.ncbi.nlm.nih.gov/10915354/

Chauhan, V., Galwankar, S., Arquilla, B., Garg, M., Somma, S. D., El-Menyar, A., Krishnan, V., Gerber, J., Holland, R., \& Stawicki, S. P. (2020). Novel Coronavirus (COVID-19):

Leveraging Telemedicine to Optimize Care While Minimizing Exposures and Viral Transmission. Journal of emergencies, trauma, and shock, 13(1), 20-24. https://doi.org/10.4103/JETS.JETS_32_20

Choi, N. G., DiNitto, D. M., Marti, C. N., \& Choi, B. Y. (2021). Telehealth Use Among Older Adults During COVID-19: Associations With Sociodemographic and Health Characteristics, Technology Device Ownership, and Technology Learning. Journal of Applied Gerontology, 073346482110473. https://doi.org/10.1177/07334648211047347

Davarpanah, A. H., Mahdavi, A., Sabri, A., Langroudi, T. F., Kahkouee, S., Haseli, S., Kazemi, M. A., Mehrian, P., Mahdavi, A., Falahati, F., Tuchayi, A. M., Bakhshayeshkaram, M., \& Taheri, M. S. (2020). Novel Screening and Triage Strategy in Iran During Deadly Coronavirus Disease 2019 (COVID-19) Epidemic: Value of Humanitarian Teleconsultation Service. Journal of the American College of Radiology, 17(6), 734-738. https://doi.org/10.1016/j.jacr.2020.03.015

Doraiswamy, S., Jithesh, A., Mamtani, R., Abraham, A., \& Cheema, S. (2021). Telehealth Use in Geriatrics Care during the COVID-19 Pandemic-A Scoping Review and Evidence Synthesis. International Journal of Environmental Research and Public Health, 18(4), 1755. https://doi.org/10.3390/ijerph18041755

Doraiswamy, S., Mamtani, R., Ameduri, M., Abraham, A., \& Cheema, S. (2020). Respiratory epidemics and older people. Age and Ageing, 49(6), 896-900. https://doi.org/10.1093/ageing/afaa151

Fortney, J. C., Pyne, J. M., Edlund, M. J., Williams, D. K., Robinson, D. E., Mittal, D., \& Henderson, K. L. (2007). A randomized trial of telemedicine-based collaborative care for depression. Journal of general internal medicine, 22(8), 1086-1093. https://doi.org/10.1007/s11606-007-0201-9 
Foster, M. V., \& Sethares, K. A. (2014). Facilitators and Barriers to the Adoption of Telehealth in Older Adults. CIN: Computers, Informatics, Nursing, 32(11), 523-533. https://doi.org/10.1097/cin.0000000000000105

Greenhalgh, T., Koh, G. C. H., \& Car, J. (2020a). Covid-19: a remote assessment in primary care. BMJ, m1182. https://doi.org/10.1136/bmj.m1182

Greenhalgh, T., Wherton, J., Shaw, S., \& Morrison, C. (2020b). Video consultations for covid-19. BMJ, m998. https://doi.org/10.1136/bmj.m998

Hollander, J. E., \& Carr, B. G. (2020). Virtually Perfect? Telemedicine for Covid-19. New England Journal of Medicine, 382(18), 1679-1681. https://doi.org/10.1056/nejmp2003539

Ioannidis, J. P., Axfors, C., \& Contopoulos-Ioannidis, D. G. (2020). Population-level COVID19 mortality risk for non-elderly individuals overall and for non-elderly individuals without underlying diseases in pandemic epicenters. Environmental Research, 188, 109890. https://doi.org/10.1016/j.envres.2020.109890

Jahanshir, A., Karimialavijeh, E., Sheikh, H., Vahedi, M., \& Momeni, M. (2017). Smartphones and Medical Applications in the Emergency Department Daily Practice. Emergency (Tehran, Iran), 5(1), e14.

Jiang, F., Deng, L., Zhang, L., Cai, Y., Cheung, C. W., \& Xia, Z. (2020). Review of the Clinical Characteristics of Coronavirus Disease 2019 (COVID-19). Journal of General Internal Medicine, 35(5), 1545-1549. https://doi.org/10.1007/s11606-020-05762-w

Jiang, X., Deng, L., Zhu, Y., Ji, H., Tao, L., Liu, L., Yang, D., \& Ji, W. (2020). Psychological crisis intervention during the outbreak period of new coronavirus pneumonia from experience in Shanghai. Psychiatry Research, 286, 112903. https://doi.org/10.1016/j.psychres.2020.112903

Kang, L., Li, Y., Hu, S., Chen, M., Yang, C., Yang, B. X., Wang, Y., Hu, J., Lai, J., Ma, X., Chen, J., Guan, L., Wang, G., Ma, H., \& Liu, Z. (2020). The mental health of medical workers in Wuhan, China dealing with the 2019 novel coronavirus. The lancet. Psychiatry, 7(3), e14. https://doi.org/10.1016/S2215-0366(20)30047-X

Kruse, C., Krowski, N., Rodriguez, B., Tran, L. Vela, J., Brooks, M. (2017). Telehealth and patient satisfaction: A systematic review and narrative analysis. BMJ Open. 7.DOI: e016242. 10.1136/bmjopen-2017-016242.

Lam, K., Lu, A. D., Shi, Y., \& Covinsky, K. E. (2020). Assessing Telemedicine Unreadiness Among Older Adults in the United States During the COVID-19 Pandemic. JAMA Internal Medicine, 180(10), 1389. https://doi.org/10.1001/jamainternmed.2020.2671

Li, H. L., Chan, Y. C., Huang, J. X., \& Cheng, S. W. (2020). Pilot Study Using Telemedicine Video Consultation for Vascular Patients' Care During the COVID-19 Period. Annals of Vascular Surgery, 68, 76-82. https://doi.org/10.1016/j.avsg.2020.06.023

Li, J., Gong, X., Wang, Z., Chen, R., Li, T., Zeng, D., \& Li, M. (2020). Clinical features of familial clustering in patients infected with 2019 novel coronavirus in Wuhan, China. Virus Research, 286, 198043. https://doi.org/10.1016/j.virusres.2020.198043

Li, W., Yang, Y., Liu, Z. H., Zhao, Y. J., Zhang, Q., Zhang, L., Cheung, T., \& Xiang, Y. T. (2020). Progression of Mental Health Services during the COVID-19 Outbreak in China. International Journal of Biological Sciences, 16(10), 1732-1738. https://doi.org/10.7150/ijbs.45120 
Lipsitch, M., Swerdlow, D. L., \& Finelli, L. (2020). Defining the Epidemiology of Covid-19 Studies Needed. New England Journal of Medicine, 382(13), 1194-1196.

https://doi.org/10.1056/nejmp2002125

Liu, L., Gu, J., Shao, F., Liang, X., Yue, L., Cheng, Q., \& Zhang, L. (2020). Application and Preliminary Outcomes of Remote Diagnosis and Treatment During the COVID-19 Outbreak: Retrospective Cohort Study. JMIR MHealth and UHealth, 8(7), e19417. https://doi.org/10.2196/19417

Liu, S., Yang, L., Zhang, C., Xiang, Y. T., Liu, Z., Hu, S., \& Zhang, B. (2020). Online mental health services in China during the COVID-19 outbreak. The Lancet Psychiatry, 7(4), e17-e18. https://doi.org/10.1016/s2215-0366(20)30077-8

McMaster University Hamilton. (2011). Critical appraisal tools to make sense of evidence. National Collaborating Center for Methods and Tools. http://dev.nccmt.ca/resources/search/87

Mehrotra, A., Jena, A. B., Busch, A. B., Souza, J., Uscher-Pines, L., \& Landon, B. E. (2016). Utilization of Telemedicine Among Rural Medicare Beneficiaries. JAMA, 315(18), 2015. https://doi.org/10.1001/jama.2016.2186

Morenz, A. M., Wescott, S., Mostaghimi, A., Sequist, T. D., \& Tobey, M. (2019). Evaluation of Barriers to Telehealth Programs and Dermatological Care for American Indian Individuals in Rural Communities. JAMA Dermatology, 155(8), 899. https://doi.org/10.1001/jamadermatol.2019.0872

National Center for Immunization and Respiratory Diseases (U.S.). Division of Viral Diseases (2020). Interim guidance for healthcare facilities : preparing for community transmission of COVID-19 in the United States https://stacks.cdc.gov/view/cdc/85502

Nicol, G. E., Piccirillo, J. F., Mulsant, B. H., \& Lenze, E. J. (2020). Action at a Distance: Geriatric Research during a Pandemic. Journal of the American Geriatrics Society, 68(5), 922-925. https://doi.org/10.1111/jgs.16443

Ohannessian, R. (2015). Telemedicine: Potential applications in epidemic situations. European Research in Telemedicine / La Recherche Européenne En Télémédecine, 4(3), 95-98. https://doi.org/10.1016/j.eurtel.2015.08.002

Papadimos, T. J., Marcolini, E. G., Hadian, M., Hardart, G. E., Ward, N., Levy, M. M., Stawicki, S. P., \& Davidson, J. E. (2018). Ethics of Outbreaks Position Statement. Part 2: Family-Centered Care. Critical care medicine, 46(11), 1856-1860. https://doi.org/10.1097/CCM.0000000000003363

Pereira, T., Pires, G., Jorge, D., \& Santos, D. (2020). Telehealth monitoring of a hypertensive elderly patient with the new VITASENIOR-MT system: a case study. Blood pressure monitoring, 25(4), 227-230. https://doi.org/10.1097/MBP.0000000000000443

Popay, J., Roberts, H., Sowden, A., Petticrew, M., Arai, L., Rodgers, M., Britten, N., Roen, K. Duffy, S. (2006). Guidance on the conduct of narrative synthesis in systematic reviews: A product from the ESRC. Methods Programme. DOI: 10.13140/2.1.1018.4643.

Portnoy, J., Waller, M., \& Elliott, T. (2020). Telemedicine in the Era of COVID-19. The journal of allergy and clinical immunology. In practice, 8(5), 1489-1491.

https://doi.org/10.1016/j.jaip.2020.03.008 
Reeves, J. J., Hollandsworth, H. M., Torriani, F. J., Taplitz, R., Abeles, S., Tai-Seale, M., Millen, M., Clay, B. J., \& Longhurst, C. A. (2020). Rapid response to COVID-19: health informatics support for outbreak management in an academic health system. Journal of the American Medical Informatics Association, 27(6), 853-859.

https://doi.org/10.1093/jamia/ocaa037

Sauers-Ford, H. S., Hamline, M. Y., Gosdin, M. M., Kair, L. R., Weinberg, G. M., Marcin, J. P., \& Rosenthal, J. L. (2019). Acceptability, Usability, and Effectiveness: A Qualitative Study Evaluating a Pediatric Telemedicine Program. Academic Emergency Medicine, 26(9), 1022-1033. https://doi.org/10.1111/acem.13763

Shaker, M. S., Oppenheimer, J., Grayson, M., Stukus, D., Hartog, N., Hsieh, E. W., Rider, N., Dutmer, C. M., Vander Leek, T. K., Kim, H., Chan, E. S., Mack, D., Ellis, A. K., Lang, D., Lieberman, J., Fleischer, D., Golden, D. B., Wallace, D., Portnoy, J., . . . Greenhawt, M. (2020). COVID-19: Pandemic Contingency Planning for the Allergy and Immunology Clinic. The Journal of Allergy and Clinical Immunology: In Practice, 8(5), 1477-1488.e5. https://doi.org/10.1016/j.jaip.2020.03.012

Smith, A. C., Thomas, E., Snoswell, C. L., Haydon, H., Mehrotra, A., Clemensen, J., \& Caffery, L. J. (2020). Telehealth for global emergencies: Implications for coronavirus disease 2019 (COVID-19). Journal of Telemedicine and Telecare, 26(5), 309-313. https://doi.org/10.1177/1357633×20916567

Soroosh, D., \& Javadinia, S. A. (2020). The COVID-19 outbreak and Oncology Centers in Iran. International Journal of Cancer Management, 13(6). https://doi.org/10.5812/ijcm.103283

Southern Connecticut University. (2021). SCSU Research Guides: *Nursing*: Literature, Systematic, and Integrative Reviews. Buley Library. https://libguides.southernct.edu/nursing/reviews

Southern Connecticut University. (2021). SCSU Research Guides: *Nursing*: Literature, Systematic, and Integrative Reviews. Buley Library. https://libguides.southernct.edu/nursing/reviews

Tan, L. F., Ho Wen Teng, V., Seetharaman, S. K., \& Yip, A. W. (2020). Facilitating telehealth for older adults during the COVID -19 pandemic and beyond: Strategies from a Singapore geriatric center. Geriatrics \& Gerontology International, 20(10), 993-995. https://doi.org/10.1111/ggi.14017

Tenforde, A. S., laccarino, M. A., Borgstrom, H., Hefner, J. E., Silver, J., Ahmed, M., Babu, A. N., Blauwet, C. A., Elson, L., Eng, C., Kotler, D., Homer, S., Makovitch, S., McInnis, K. C., Vora, A., \& Borg-Stein, J. (2020). Telemedicine During COVID-19 for Outpatient Sports and Musculoskeletal Medicine Physicians. PM\&R, 12(9), 926-932. https://doi.org/10.1002/pmrj.12422

Valle, J., Godby, T., Paul, D. P., Smith, H., \& Coustasse, A. (2017). Use of Smartphones for Clinical and Medical Education. The Health Care Manager, 36(3), 293-300. https://doi.org/10.1097/hcm.0000000000000176

Van der Hoek, L., Pyrc, K., Jebbink, M. F., Vermeulen-Oost, W., Berkhout, R. J. M., Wolthers, K. C., Wertheim-van Dillen, P. M. E., Kaandorp, J., Spaargaren, J., \& Berkhout, B. (2004). Identification of a new human coronavirus. Nature Medicine, 10(4), 368-373. https://doi.org/10.1038/nm1024 
Wax, R. S., \& Christian, M. D. (2020). Practical recommendations for critical care and anesthesiology teams caring for novel coronavirus (2019-nCoV) patients. Directives concrètes à l'intention des équipes de soins intensifs et d'anesthésiologie prenant soin de patients atteints du coronavirus 2019-nCoV. Canadian journal of anaesthesia = Journal canadien d'anesthesie, 67(5), 568-576. https://doi.org/10.1007/s12630-02001591-X

World Health Organization. (2020a). Coronavirus disease (COVID-19). WHO. https://www.who.int/emergencies/diseases/novel-coronavirus-2019

Wosik, J., Fudim, M., Cameron, B., Gellad, Z. F., Cho, A., Phinney, D., Curtis, S., Roman, M., Poon, E. G., Ferranti, J., Katz, J. N., \& Tcheng, J. (2020). Telehealth transformation: COVID-19 and the rise of virtual care. Journal of the American Medical Informatics Association, 27(6), 957-962. https://doi.org/10.1093/jamia/ocaa067

Yang, Y., Zhou, Y., Liu, X., \& Tan, J. (2020). Health services provision of 48 public tertiary dental hospitals during the COVID-19 epidemic in China. Clinical Oral Investigations, 24(5), 1861-1864. https://doi.org/10.1007/s00784-020-03267-8

Zhai, Y., Wang, Y., Zhang, M., Gittell, J. H., Jiang, S., Chen, B., Cui, F., He, X., Zhao, J., \& Wang, X. (2020). From Isolation to Coordination: How Can Telemedicine Help Combat the COVID-19 Outbreak? MedRxiv. https://doi.org/10.1101/2020.02.20.20025957

Zhou, T., Huang, S., Cheng, J., \& Xiao, Y. (2020). The Distance Teaching Practice of Combined Mode of Massive Open Online Course Micro-Video for Interns in Emergency Department During the COVID-19 Epidemic Period. Telemedicine and EHealth, 26(5), 584-588. https://doi.org/10.1089/tmj.2020.0079

Zhou, X., Snoswell, C. L., Harding, L. E., Bambling, M., Edirippulige, S., Bai, X., \& Smith, A. C. (2020a). The Role of Telehealth in Reducing the Mental Health Burden from COVID-19. Telemedicine and E-Health, 26(4), 377-379. https://doi.org/10.1089/tmj.2020.0068 


\section{APPENDIX}

Table 1. Article Sample Characteristics

\begin{tabular}{|c|c|c|c|c|}
\hline Author/Year/Country & Design & Samples and Sample Size & $\begin{array}{l}\text { Data Collection Method and } \\
\text { Instruments }\end{array}$ & $\begin{array}{l}\text { Level of } \\
\text { Evidence }\end{array}$ \\
\hline $\begin{array}{l}\text { Choi et al. (2021) } \\
\text { United States of America }\end{array}$ & Case Study & $\begin{array}{l}\text { participants aged } 65 \\
\text { and above } \\
2696 \text { self-respondents } \\
\text { (with or without the } \\
\text { assistance of a proxy) } \\
\text { and } 561 \text { proxy/unknown } \\
\text { respondents } \\
\text { represented a total of } \\
32.7 \text { million Medicare } \\
\text { beneficiaries aged } 70 \\
\text { and over. }\end{array}$ & $\begin{array}{l}\text { Used the National Health and } \\
\text { Aging Trend Study Round } 10 \\
\text { (NHATS R10) public-use data files, } \\
\text { including a postal survey on } \\
\text { participants' experiences during } \\
\text { the COVID-19 outbreak. } \\
\text { Statistics are collected from a } \\
\text { nationally representative panel of } \\
\text { Medicare }\end{array}$ & LOE VI \\
\hline $\begin{array}{l}\text { Zhai e.t al. (2020) } \\
\text { China, United Kingdom }\end{array}$ & Case Studies & $\begin{array}{l}\text { The ETCS delivered } \\
\text { telemedicine } \\
\text { consultations to } 63 \\
\text { severe cases and } 591 \\
\text { patients with mild to } \\
\text { moderate respiratory } \\
\text { diseases between } \\
\text { January } 28 \text { and February } \\
17,2020 . \text { As of February } \\
17,2020,420 \text { cases had } \\
\text { been cured and patients } \\
\text { discharged from } \\
\text { hospitals. }\end{array}$ & Online Interview & LOE VI \\
\hline $\begin{array}{l}\text { L. Liu et al. (2020) } \\
\text { China }\end{array}$ & $\begin{array}{l}\text { Descriptive } \\
\text { Retrospective } \\
\text { review }\end{array}$ & $\begin{array}{l}4589 \text { patients; } \\
58 \% \text { females and } 42 \% \\
\text { males; Age range - } 78 \\
\text { days old to } 85 \text { years old. } \\
81 \% \text { were aged } 20-39 \text { age } \\
\text { group }\end{array}$ & Electronic Questionnaire & LOE VI \\
\hline $\begin{array}{l}\text { Nicol et al. (2020) } \\
\text { United States of America, } \\
\text { Canada }\end{array}$ & $\begin{array}{l}\text { Cross- } \\
\text { sectional } \\
\text { Study }\end{array}$ & $\begin{array}{l}\text { Older adults; } 18 \text { above } \\
\text { including elderly }\end{array}$ & e-mailed surveys & LOE VI \\
\hline $\begin{array}{l}\text { Li et al. (2020) } \\
\text { Hong Kong }\end{array}$ & $\begin{array}{l}\text { Descriptive } \\
\text { Pilot study }\end{array}$ & $\begin{array}{l}114 \text { patients. Mean age }= \\
60(\text { SD } 15.2) \text { years old; } \\
65 \% \text { men; } 81 \% \text { were post- } \\
\text { op patients. }\end{array}$ & Questionnaire & LOE VI \\
\hline $\begin{array}{l}\text { Tenforde et al. (2020) } \\
\text { United States of America }\end{array}$ & Descriptive & $\begin{array}{l}19 \text { patients; } 13 \\
\text { physiatrists; mostly } \\
\text { females aged 34-64 }\end{array}$ & Anonymous survey & LOE VI \\
\hline
\end{tabular}




\begin{tabular}{|l|l|l|l|c|}
\hline $\begin{array}{l}\text { Pereira et al. (2020) } \\
\text { United States of America }\end{array}$ & Case Study & $\begin{array}{l}\text { male hypertensive } \\
\text { patient, aged 81 years } \\
\text { old, under anti- } \\
\text { hypertensive treatment, } \\
\text { with epilepsy, arthritis } \\
\text { and paroxistic atrial } \\
\text { fibrillation as major } \\
\text { comorbidities }\end{array}$ & Interview & \\
& & $\begin{array}{l}\text { 4525 adults; 1925 (43\%) } \\
\text { men, 2600 (57\%) women; } \\
\text { avarage age was 79.6 } \\
\text { years old }\end{array}$ & Survey assisted by family assistant & LOE VI \\
\hline $\begin{array}{l}\text { Lam et al. (2020) } \\
\text { United States }\end{array}$ & $\begin{array}{l}\text { Cross- } \\
\text { sectional } \\
\text { Study }\end{array}$ & & & \\
\end{tabular}

Table 3. Telehealth, its function and its effects on the elderly patients

\begin{tabular}{|c|c|c|c|}
\hline Author/Year/Country & Telehealth & Content & Effects \\
\hline $\begin{array}{l}\text { Choi et al. (2021) United } \\
\text { States of America }\end{array}$ & $\begin{array}{l}\text { Phone calls, } \\
\text { emails/texts or social } \\
\text { media messages, and } \\
\text { video calls (including } \\
\text { Zoom, FaceTime, and } \\
\text { other online } \\
\text { videoconferencing) }\end{array}$ & $\begin{array}{l}\text { Make healthcare use } \\
\text { more convenient for } \\
\text { many individuals, and } \\
\text { some healthcare } \\
\text { professionals are } \\
\text { expected to continue to } \\
\text { use telehealth post- } \\
\text { COVID-19 }\end{array}$ & $\begin{array}{l}\text { Eliminated the need for patients to be } \\
\text { transported to overcrowded hospitals. } \\
\text { Provided near-real-time advice from } \\
\text { experts all throughout the country and } \\
\text { the world. } \\
\text { Satisfied a local need based on COVl19 } \\
\text { Protocols; may lower risk of getting } \\
\text { infected by going out for medical } \\
\text { maintenance }\end{array}$ \\
\hline $\begin{array}{c}\text { Zhai e.t al. (2020) China, } \\
\text { United Kingdom }\end{array}$ & $\begin{array}{l}\text { Mobile video } \\
\text { conferencing and live } \\
\text { video conferencing }\end{array}$ & $\begin{array}{l}\text { Immediate diagnosis and } \\
\text { consultations for } \\
\text { clinicians and patients } \\
\text { with COVID-19 } \\
\text { Wireless distant patient } \\
\text { assessment } \\
\text { Remote multimodal } \\
\text { therapy } \\
\text { Patient training and } \\
\text { education }\end{array}$ & $\begin{array}{l}\text { Facilitated real-time data exchange } \\
\text { Obtained prevention and treatment } \\
\text { regulations, as well as counseling on drug } \\
\text { use and strategic planning of coronavirus } \\
\text { patients, by leading the collection, } \\
\text { storage, and processing of patient medical } \\
\text { information } \\
\text { Assist the specialized treatment team in } \\
\text { providing primary care counseling on } \\
\text { coronavirus to all physicians and nurses }\end{array}$ \\
\hline
\end{tabular}




\begin{tabular}{|c|c|c|c|}
\hline L. Liu et al. (2020) China & $\begin{array}{l}\text { Calls and a } \\
\text { computerized health } \\
\text { record (EHR) }\end{array}$ & $\begin{array}{l}\text { Assessment of patients } \\
\text { via phone calls } \\
\text { Repurposing and } \\
\text { engaging the EHR } \\
\text { optimization team to } \\
\text { teach end users' video } \\
\text { visit process } \\
\text { Screening or treatment } \\
\text { for a patient in a mobile } \\
\text { hospital facility } \\
\text { Screening or treating a } \\
\text { patient in an emergency } \\
\text { care setting } \\
\text { Providing decision } \\
\text { assistance for individuals } \\
\text { in need of testing }\end{array}$ & $\begin{array}{l}\text { Dealing with the worries of patients } \\
\text { Reports on prior PUI, existing and pending } \\
\text { tests, training completion, and } \\
\text { screening/documentation compliance } \\
\text { Updated travel and symptom screening, } \\
\text { testing criteria, and clear guidance on } \\
\text { best setting and location of patient care } \\
\text { Clinical decision support on testing } \\
\text { criteria, recommended additional work- } \\
\text { up, and admission criteria Any screening } \\
\text { of patient visitors for infectious signs } \\
\text { must be documented in accordance with } \\
\text { standard procedures. } \\
\text { Providers can use this excuse letter } \\
\text { template to recommend that they work } \\
\text { from home. }\end{array}$ \\
\hline $\begin{array}{l}\text { Nicol et al. (2020) United } \\
\text { States of America, Canada }\end{array}$ & $\begin{array}{l}\text { Telephone, email, and } \\
\text { videoconferencing are } \\
\text { examples of digital } \\
\text { channels that can be } \\
\text { used in conjunction } \\
\text { with social media }\end{array}$ & $\begin{array}{l}\text { Facilitating electronic } \\
\text { informed consent, digital } \\
\text { assessment tools, and } \\
\text { virtual study visits } \\
\text { E-consent, remote } \\
\text { examination, and } \\
\text { telephone or } \\
\text { teleconferencing visits }\end{array}$ & $\begin{array}{l}\text { Helped in implementing social distancing } \\
\text { Contributed to the implementation of } \\
\text { social distancing } \\
\text { Could be implemented away from high- } \\
\text { risk areas such as hospital grounds } \\
\text { Reduced reliance on public } \\
\text { transportation } \\
\text { Provided all components of human } \\
\text { research protection } \\
\text { Minimized viral transmission risk from in- } \\
\text { person contacts } \\
\text { Prevented morbidity in these at-risk } \\
\text { individuals during the COVID-19 pandemic }\end{array}$ \\
\hline $\begin{array}{l}\text { Li et al. (2020) } \\
\text { Hong Kong }\end{array}$ & $\begin{array}{l}\text { Phones, video cameras, } \\
\text { and laptop computers }\end{array}$ & $\begin{array}{l}\text { Telephone follow-up in a } \\
\text { variety of cancer } \\
\text { settings (endometrial, } \\
\text { prostate, lung, and } \\
\text { colorectal cancer) } \\
\text { Remote monitoring } \\
\text { Video consultations }\end{array}$ & $\begin{array}{l}\text { Reduced the chance of COVID-19 } \\
\text { transmission during radiation treatment } \\
\text { Reduced the risk of infection and the } \\
\text { risk of workforce exhaustion }\end{array}$ \\
\hline
\end{tabular}




\begin{tabular}{|c|c|c|c|}
\hline $\begin{array}{l}\text { Tenforde et al. (2020) } \\
\text { United States of America }\end{array}$ & $\begin{array}{l}\text { Phone, electronic } \\
\text { medical record, } \\
\text { messaging via patient } \\
\text { portal, digital } \\
\text { photography, } \\
\text { videography on a } \\
\text { HIPAA-compliant } \\
\text { platform, and website }\end{array}$ & $\begin{array}{l}\text { Telephone call } \\
\text { assessment in a variety } \\
\text { of cancer contexts } \\
\text { (endometrial, prostate, } \\
\text { lung, and colorectal } \\
\text { cancer) } \\
\text { Remote monitoring } \\
\text { Video consultations } \\
\text { Provide telehealth visits } \\
\text { Follow-up visits via } \\
\text { phone triage or } \\
\text { telehealth in patients } \\
\text { with urticaria, } \\
\text { angioedema, and atopic } \\
\text { dermatitis } \text { Service } \\
\text { adjustment for food } \\
\text { allergy, Eosinophilic } \\
\text { Esophagitis (EoE), drug } \\
\text { allergy, and anaphylaxis } \\
\text { Service adjustment for } \\
\text { allergic skin disorders } \\
\text { and immunodeficiency } \\
\text { Immunotherapy } \\
\text { appointments or } \\
\text { schedules }\end{array}$ & $\begin{array}{l}\text { The use of virtual care options ensured } \\
\text { care continuity and assisted in the } \\
\text { management of chronically ill patients } \\
\text { The use of telehealth in an allergy } \\
\text { practice provided an opportunity to } \\
\text { integrate telehealth into an allergy } \\
\text { practice and reduced provider exposure } \\
\text { to potentially infected patients. } \\
\text { Practice resources are not subjected to } \\
\text { the same level of taxation. }\end{array}$ \\
\hline $\begin{array}{c}\text { Pereira et al. (2020) United } \\
\text { States of America }\end{array}$ & $\begin{array}{l}\text { Online monitoring } \\
\text { gadgets }\end{array}$ & $\begin{array}{l}\text { To create personnel } \\
\text { planning } \\
\text { Utilized to conduct } \\
\text { patient billing } \\
\text { To conduct telehealth } \\
\text { visits in an appropriate } \\
\text { manner } \\
\text { Keep in touch with } \\
\text { relatives, friends, and } \\
\text { coworkers } \\
\text { If the patient is at high } \\
\text { risk, an in-person } \\
\text { evaluation or a } \\
\text { telemedicine evaluation is } \\
\text { recommended }\end{array}$ & $\begin{array}{l}\text { Improve the elderly's health and } \\
\text { quality of life through promoting safe } \\
\text { and independent living. } \\
\text { It's an 'internet-of-things' solution } \\
\text { that uses an elderly person's } \\
\text { interaction with a television to collect } \\
\text { biometric parameters and receive } \\
\text { alerts and recommendations based on } \\
\text { health and environmental sensor data. }\end{array}$ \\
\hline $\begin{array}{c}\text { Lam et al. (2020) United } \\
\text { States }\end{array}$ & $\begin{array}{l}\text { Video visits/video } \\
\text { teleconference }\end{array}$ & Live video calls & $\begin{array}{l}\text { Since it is a study that explains how the } \\
\text { tested telehealth is unready for the elders } \\
\text { there is a notion to improve them since it } \\
\text { has benefits in the other studies } \\
\text { conducted in the US. Similar to other } \\
\text { countries, telehealth has not been well } \\
\text { developed yet. }\end{array}$ \\
\hline
\end{tabular}

